\title{
LA SEXUALIDAD EN «LAS ETIMOLOGÍAS» DE SAN ISIDORO DE SEVILLA: CRISTIANISMO Y MENTALIDAD SOCIAL EN LA HISPANIA VISIGODA
}

\author{
POR \\ Henar Gallego Franco \\ Universidad de Valladolid
}

\section{RESUMEN}

La sexualidad, como una expresión más del comportamiento social, fue objeto de gran interés, en una triple vertiente adoctrinadora, controladora y represora, por parte de las autoridades eclesiásticas y civiles de la Hispania visigoda. Reflejo de su época, «Las Etimologías» de San Isidoro de Sevilla dan testimonio de la moral sexual cristiana oficial, que prima el valor de la castidad y se ajusta fielmente a los valores de la doctrina patrística cristiana, y muestra su cristalización en un conjunto de directrices y consejos para un "sano y correcto» uso de la sexualidad que calarán hondamente en la mentalidad social hispanovisigoda.

PALABRAS CLAVE: Sexualidad, Sociedad hispanovisigoda, Isidoro de Sevilla.

\begin{abstract}
Human sexuality, as an expression of the social behaviour, was a question of great interest in a triple way (educational, controlling and repressive) for the ecclesiastic and civil authorities in Visigothic Spain. As a reflection of its time, Etymologiae by Saint Isidore of Seville gives evidence of the official christian sexual morality, which places a high value on chastity and follows faithfully the principles of the patristic teaching, and shows its crystallization in a group of guidelines and advices for a healthy and correct use of sex which will penetrate deeply in the social mentality of Visigothic Spain.
\end{abstract}

KEY WORDS: Sexuality, Spanish-Visigothic society, Isidore of Seville. 
Obra cumbre del renacer cultural hispanovisigodo, «Las Etimologías» (Etymologiae) de San Isidoro de Sevilla ponen a disposición del historiador e investigador un inmenso repertorio enciclopédico, razonadamente ordenado, de cuanto de lo sagrado y profano podía saberse en la España del s.VII d.C. ${ }^{1}$. El vigoroso caudal de los vastos conocimientos de su autor toma la forma de un procedimiento etimológico, de manera que con ocasión de explicar la etimología de los diferentes vocablos y palabras se pretende acceder a una mejor comprensión y un mayor conocimiento del mundo en general. Destinada a servir de referencia a un público relativamente extenso, en especial al hombre culto medio, Etymologiae supera su inicial vocación didáctica y pastoral para ofrecer una valiosa y original síntesis de la cultura bíblica y grecolatina unidas, buscando asentar los pilares culturales de las nuevas élites sociales hispanovisigodas, que se sentían herederas tanto de los senadores romanos como de los señores godos, y que hicieron de su ferviente cristianismo una de sus más genuinas señas de identidad común ${ }^{2}$. Ninguno de los veinte libros en los que se divide el contenido de Etymologiae aborda de forma monográfica el tema que nos ocupa, la sexualidad. Sin embargo, un análisis detallado de toda la obra nos permite ciertamente extraer un conjunto de referencias de naturaleza diversa que perfilan los rasgos básicos de la concepción del autor en relación a los aspectos relacionados con el sexo y la moral sexual, sin duda profundamente ligados a la mentalidad social de la época. En el seno de la sociedad hispanovisigoda del s.VII, Isidoro nos ofrece prioritariamente, en relación a esta cuestión, el testimonio de un hombre de Iglesia, firmemente anclado en la doctrina cristiana y

1 Las fuentes hispanovisigodas citadas se refieren a estas ediciones: SAN ISIDORO DE SEVILLA, Etimologias, vol. I y II, Biblioteca de Autores Cristianos, Madrid, 1982; J. VIVES, Concilios visigóticos e hispanorromanos, Barcelona-Madrid, 1963; para la Lex Visigothorum (L.V.): Liber Judicum/El Fuero Juzgo, Los códigos españoles concordados y anotados, Madrid, Imprenta La Publicidad, 1847.

2 J. MADOZ, San Isidoro de Sevilla, León, 1960, pp.53-64; M. C. DÍAZ Y DÍAZ, «Introducción», en SAN IsIDORo DE SEVILlA, Etimologias, vol. I, Biblioteca de Autores Cristianos, Madrid, 1982, pp.163-164, 184, 214; L. A. GARCÍA MORENO, «La Andalucía de San Isidoro», en Actas del II Congreso de Historia de Andalucía (Córdoba, 1991). Historia Antigua, Córdoba, 1994, p. 579. Sobre la síntesis de cristianismo y cultura clásica en la obra de Isidoro, J. FONTAINE, Isidore de Séville et la culture classique dans l'Espagne wisigothique, París, 1959; P. M. BASSETT, The Concept of Christian Society and Culture in the Writings of Isidore of Seville, Tesis Duke University, 1968; F.J. LOZANO SEBASTIÁN, San Isidoro y la filosofia clásica, León, 1982; N. MESSINA, «Le citazioni classiche nelle Etymologiae di Isidoro di Siviglia», en Archivos Leoneses, 68 (jul.-dic. 1980) 205-265. Ahora bien, aunque el legado de la cultura clásica fuera para Isidoro una pieza importante en el desarrollo de su personal proyecto educativo, la complejidad del análisis de los autores paganos y cristianos por él empleados, bien de primera o de segunda mano, resulta bien patente en el exhaustivo análisis de las fuentes del libro VIII de Etymologiae en A. VALASTRO CANALE, Herejías y sectas en la Iglesia Antigua. El octavo libro de las Etimologías de Isidoro de Sevilla y sus fuentes, Universidad Pontificia Comillas, Madrid, 2000, cfr. especialmente el amplio apéndice final (pp. 85-241).

Textos medievales

Hispania Sacra 55 (2003) 
eclesiástica más ortodoxa acerca de la sexualidad ${ }^{3}$, vertiente que prevalece sobre otras posibles perspectivas, como aristócrata influyente e intelectual de exquisita y amplísima formación ${ }^{4}$. Finalmente, no podemos obviar el hecho de que el enorme prestigio social, intelectual y religioso de San Isidoro de Sevilla en la sociedad de su tiempo se tradujo poco después de su muerte en su elevación al rango de autoridad indiscutida, lo que otorgó al conjunto de doctrinas, concepciones, definiciones y opiniones expresadas en Etymologiae, como también en las restantes obras del autor, una sobresaliente aceptación y difusión en la sociedad de su tiempo y de los inmediatamente posteriores, en los medios eclesiásticos, teológicos, intelectuales, y en el tipo medio de hombre culto en general ${ }^{5}$.

La concepción de la sexualidad y de su ejercicio que aflora en Etymologiae es marcadamente negativa y restrictiva, en evidente sintonía con la moral cristiana de la época. Ya la imagen del ejercicio de la sexualidad que proyectan los cánones de los Concilios hispanovisigodos es muy restrictiva, considerando el deseo sexual como resultado de la fragilidad humana y parte integrante de los vicios, a los que el ser humano se haya especialmente expuesto en la adolescencia o juventud, mientras que la madurez del tiempo trae consigo la continencia ${ }^{6}$. Las trasgresiones en el terreno del comportamiento sexual (fornica-

3 Sobre la sexualidad en el cristianismo eclesiástico, P. J. PAYER, Sex and the Penitencials. The Development of a Sexual Code, 550-1150 d.C., Toronto, 1984; A. BRUNDAGE, Law, Sex and Christian Society in Medieval Europe, Chicago, 1987; P. BROWN, El cuerpo y la sociedad. Los cristianos y la renuncia sexual, Barcelona, 1993 (1988); K. DESCHNER, Historia sexual del cristianismo, Zaragoza, 1993 (1974). Más específicamente, sobre la posición de la mujer y su sexualidad en el cristianismo primitivo, cfr. M. IBARRA, Mulier fortis. La mujer en las fuentes cristianas (280-313 d.C.), Zaragoza, 1990.

4 Miembro de una rica familia aristocrática latifundista de las élites sociales de la España meridional, que ejerció una influencia de primer orden en el devenir político del Reino Visigodo de Toledo en el s.VII d.C., activos en especial en los entresijos de la corte visigoda y sus disputas dinásticas, cfr. M. C. DÍAZ Y DÍAZ, «Introducción», en SAN ISIDORO DE SEVILlA, Etimologías..., pp.95-113; L. A. GARCÍA MORENO, «La Andalucía de San Isidoro», en Actas del II Congreso de Historia de Andalucía (Córdoba, 1991). Historia Antigua, Córdoba, 1994, pp. 555-556, 564-579.

5 M. C. DÍAZ Y DíAZ, «Introducción», en SAN ISIDORO DE SEVILLA, Etimologías, vol. I, Biblioteca de Autores Cristianos, Madrid, 1982, pp.215-223.

6 Toledo VI (638 d.C.), 6, «La vida es propensa a la voluptuosidad y la naturaleza es imitadora de los vicios» (Proclivis cursus ast ad voluptatem et imitatrix natura vitiorim), y 7 (sobre los penitentes adolescentes casados) «... hasta que con la madurez del tiempo pueda conseguir el estado de continencia. Lo cual nosotros creemos que ha sido mandado igualmente de los hombres como de las mujeres, aunque no de un modo general y enteramente conforme a la disciplina, sino que consta que ha sido concedido por nosotros a la humana fragilidad...» (... quousque possit adipisci temporis maturitatem continetiae statum: quod nos sicut de viris ita et de foeminis aequo modo censemus non quidem generaliter et legitime praeceptum, sed constat a nobis pro humana fragilitate indultum...). Tarragona (516 d.C.), 1, los testigos de vista en las casas de los sacerdotes han de ser «entrados en años» (...testem solati sui et aetate probidum adhibeant secum). Toledo IV (633 d.C.), 24, «Cualquier edad del hombre a partir de la adolescencia es inclinada al mal, pero nada más inconstante que la vida de 
ción, adulterio, incesto, homosexualidad, zoofilia) tanto de clérigos como de seglares, se califican en las actas de los concilios, con un lenguaje duro e impactante, como crímenes nefandos, horrendos, execrables, vergonzosos, o de abominaciones ${ }^{7}$. Encontramos además que la legislación civil asume en su práctica totalidad la doctrina eclesiástica en cuestiones de moral sexual, y así la Lex Visigothorum se muestra muy dura respecto a las trasgresiones de la moral sexual, cuales son el rapto y violación de mujeres, los adulterios y la fornicación, el incesto, la homosexualidad o sodomía, la prostitución, la falta de castidad de los clérigos, de manera que lo que para las autoridades eclesiásticas son pecados mortales sancionados en los cánones conciliares, para las autoridades laicas son delitos punibles y de hecho castigados en la legislación civil ${ }^{8}$.

\footnotetext{
los jóvenes;... para que (los clérigos adolescentes) pasen los años de la edad resbaladiza, no en la lujuria, sino en las disciplinas eclesiásticas...» (Prona est omnis aetas ab adolescentia in malum, nicil enim incertius quam vita adolescentium; ... ut lubricar aetatis annos non in luxuria sed in disciplinis ecclesiasticis agant...). Cfr. L. GARCÍA IGLESIAS, «La edad difícil y la sexualidad adolescente en la España visigoda», en HAnt, VI (1976) 80-84.

7 Toledo II (527 d.C.), carta del obispo Montano a los palentinos: «crímenes nefandos» (ad sceleris nefarii effectum) son los abusos sexuales de Prisciliano; Lérida (546 d.C.), 5, compara reincidir en el pecado carnal como los perros reinciden en el vómito ( $Q$ uod si iterato velut canes ad vomitum reversi fuerint...), la imagen no puede ser más desagradable; Toledo IV (633 d.C.), 21, los obispos han de permanecer libres de «toda suciedad de la carne» (...et ab omni inquinamneto carnis liberi maneamus...). Braga II (572 d.C.), 1 califica de crimen (diversa crimina) el adulterio; Toledo III (589 d.C.), 17 califica de crimen horrendo (horrendum facinus; idem scelus) el aborto. Toledo IV (633 d.C.), 52 califica de crimen (crimina) la falta de castidad de los sacerdotes. Toledo VIII (653 d.C.), califica de crímenes la violación de una virgen sagrada y el adulterio (horrendam criminum; in stupri flagitium). Igualmente los cánones 4, 5 y 6 de Toledo VIII se refieren a las trasgresiones de la castidad en los clérigos como «inmundicia» (inmunditia), «crímenes execrables» (execrabilibus flagitiis), «inmundo y execrable contacto» (inmunda societate ex execranbili turpari), «vergonzoso crimen» (flagitii dedecus), «abominaciones» (abominanda), «inmundicia de la carne» (carnis inmunditia), el canon 10 de Toledo IX (655 d.C.) se refiere a ello como «crímenes» (scelerum), y el decreto acerca del obispo Potamio en Toledo X (656 d.C.) habla de «ensuciarse de fornicación con mujer» (foemineo sorduisset stupro). El propio Isidoro como obispo metropolitano de Sevilla, participó en el segundo concilio de Sevilla del 619 d.C., y el cuarto concilio de Toledo del 633 d.C., cfr. J. VIVES, Concilios visigóticos e hispanorromanos, Barcelona-Madrid, 1963, pp.185, 222.

8 Cfr. L. V., III, 3 (De raptu virginum vel viduarum); III, 4 (De adulteriis); III, 5 (De incestis, et apostatis, atque masculorum concubinatoribus). Estos delitos se condenan igualmente en la legislación canónica. Así, sobre la transgresión de la castidad en los hombres y mujeres consagrados a Dios, cfr. Tarragona (516 d.C.), 1, 9; Gerona (517 d.C.), 6, 7, 8; Toledo II (527 d.C.), 1, 3; Lérida (546 d.C.), 5, 6, 15; Toledo III (589 d.C.), 5, 10; Sevilla 1 (590 d.C.), 3; Toledo (597 d.C.), 1; Huesca (598 d.C.); Egara (614 d.C.); Barcelona II (599 d.C.), 4; Sevilla II (619 d.C.), 4, 11; Toledo IV (633 d.C.), 19, 21, 22, 23, 24, 42, 43, 44, 42, 55, 56; Toledo VI (638 d.C), 6, 7; Toledo VIII (653 d.C.), 4, 5, 6, 7; Toledo IX (655 d.C.), 10; Mérida (666 d.C.), 4; Toledo XI (675 d.C.), 5; Braga III (675 d.C.), 4. Sobre el incesto, Toledo II (527 d.C.), 5; Lérida (546 d.C.), 4. Sobre le aborto, Lérida (546 d.C.), 2; Toledo III (589 d.C.), 17. Sobre el divorcio, Toledo XII (681 d.C.), 8. Sobre la sodomía, Toledo XVI (693 d.C.), 3.
}

Textos medievales

Hispania Sacra 55 (2003) 
San Isidoro en Etymologiae reprueba en general el apetito por los placeres, entre ellos, obviamente, el sexo. El deseo sexual, que considera aparejado al amor-pasión que inflama y acalora a la persona, se traduce en pecado de fornicación, y así convierte a Eros/Cupido, el dios grecorromano del amor, en el demonio con alas de la fornicación ${ }^{9}$. El deseo sexual toma así la forma de lujuria y corrupción libidinosa, una de las tres pasiones, junto con la ira y la avaricia, que se hallan en el origen de todos los pecados y llevan al hombre a cometer graves delitos y crímenes: «Facinus (delito) deriva de facere (hacer) un mal, porque causa daño a otra persona. Flagitium (ignominia) deriva de flagitare (intentar seducir); es una corrupción libidinosa por la que uno se hace daño a sí mismo. Estos dos son el origen de todos los pecados», así como «Dicen también que las Furias son tres mujeres con cabellos de serpientes, como tres son las pasiones que provocan en el espíritu del hombre las mayores turbaciones. Y que a veces lo empujan al delito de forma que no le permite tener en cuenta ni su fama ni el peligro al que sé expone: la ira, que ansía la vengan$\mathrm{za}$; la avaricia, que ambiciona riquezas, y la lujuria, que busca los placeres» ${ }^{10}$. Sensualidad es así igual a maldad ${ }^{11}$. Además, Isidoro llega a conectar la etimología de los propios términos «pecado» y «pecador», en su sentido genérico, con el pecado concreto de fornicación: «Peccator (pecador): vocablo derivado

9 Etymol., VIII, 11, 80: Cupidinem vocatum ferunt propter amorem. Est enim daemon fornicationis. Qui ideo alatus pingitur, quia nihil amantibus levius, nihil mutabilius invenitur. Puer pingitur, quia stultus est et irationabilis amor. Sagittam et facem tenere fingitur. Sagittam, quia amor cor vulnerat; facem, quia inflammat (Se dice que Cupido se llama así porque es el amor. Es el demonio de la fornicación, y se lo pinta dotado de alas porque nada hay más veleidoso que un amante, ni tampoco más mudable. Se lo pinta portando una flecha y una antorcha: una flecha, porque el amor hiere el corazón; una antorcha, porque lo inflama). También en Etymol., VIII, 11, 78 asocia calor con sexo: Ideo autem Venerem Vulcani dicunt uxorem, quia Venerium officium nonnisi calore consistit (Dicen que Venus es la esposa de Vulcano, porque la relación venérea no se produce más que con el calor), y la misma relación en Etymol. XI, 2, 24 (fuego/concupiscencia), IX, 5, 25 (soplo ardiente que preña), XI, 1, 97 (calor venéreo), XI, 1, 125 (hígado/fuego-calor/líbido-concupiscencia), XII, 1, 14 (miembro fálico ardiente), XIII, 13, 4 (ardores de la lascivia), XVII, 9, 42 (la ajedra, planta afrodisiaca, es cálida y casi ardiente), XVII, 10, 21 (la col rizada, afrodisiaca, tiene propiedades abrasadoras).

10 Etymol., V, 26, 2-3: Facinus dictum a faciendo malum, quod noceat alteri. Fagitium a flagitando corrptelam libidinis, qua noceat sibi.; VIII, 11, 95: Aiunt et tres Furias feminas crinitas serpentibus, propter tre affectus, quae in animis hominum multas perturbationes gignunt, et interdum cogunt ita delinquere, ut nec famae nec periculi sui respectum habere permittant. Ira, quae vindictam cupit: cupiditas, quae desiderat opes: libido, quae appetit voluptates. Aquí son las míticas Furias de la antigüedad clásica las que prestan su imagen a Isidoro para encarnar la ira, la avaricia y la lujuria, fuente de todos los delitos y pecados, fusionando hábilmente el autor antigüedad pagana y cristianimo.

11 Etymol., X, C, 35: Continens non solum in castitate dicitur, sed et in cibo et potu, in ira quoque et vexatione mentis et detrahendi libidine. Et continens, quod se a multis malis abstineat (Continente se dice no sólo hablando de la castidad, sino también del que se «contiene» en la comida y en la bebida, así como también el que reprime su ira, conteniendo la violencia de su espíritu y la sensualidad. Es «continente», por lo tanto, el que se abstiene de muchos males). 
de pellex, es decir, «puta», como si dijéramos pellicator (putero); este nombre lo aplicaban los antiguos únicamente a este tipo de pecadores; más tarde el vocablo acabó por designar a toda clase de pecadores» ${ }^{12}$. Ciertamente obtenemos la impresión de que el de fornicación es el pecado por excelencia. Bien sintomático de esta concepción es que uno de los dos ejemplos que Isidoro menciona como muestra de «precepto», en su significado de «algo que nos enseña qué debemos evitar hacer», es «no fornicarás» ${ }^{13}$.

Continuando con esta línea de pensamiento, el autor hace un repaso en Etymologiae de una serie de delitos y crímenes que se fraguan en la incontinencia del deseo sexual de las personas, y que se encuentran tipificados y sancionados en la legislación civil y canónica hispanovisigoda. Es el caso del adulterio ${ }^{14}$, un comportamiento sexual incompatible con la virtud y el buen nombre ${ }^{15}$, el rapto y el estupro ${ }^{16}$, el incesto, que aplica también a los que mantienen relaciones sexuales con vírgenes consagradas ${ }^{17}$, y la prostitución. Parece que este último delito producía especial preocupación en el autor, ya que referidas a las prostitutas y meretrices y a sus actividades encontramos una repeti-

12 Etymol., X, P, 228: Peccator a pelice, id est meretrice vocatus, quasi pelicator; quod nomen apud antiquos tantum flagitiosum significabat, postea transiit hoc vocabulum in appellationum omnium iniquorum.

13 Etymol., VI, 8, 10, siendo el segundo «no cometerás hurto»: Quid non faciendum, ut: «Non moechaberis», «Non furtum facies».

14 Etymol., V, 26, 13: Adulterium est inlusio alieni coniugii, quod, quia alterius torum commaculavit, adulterii nomen accepit (Adulterio es el engaño que se hace a otro matrimonio. Recibió el nombre de adulterio porque se mancilla el lecho de otro); X, A, 10: Adulter, violator maritalis pudoris, eo quod alterius torum polluat (Adúltero, el que viola la honestidad del matrimonio, porque mancilla el lecho de otro).

15 Etymol., II, 12, 3 y 4: ... Item inhonestum tractatur aut in dictis aut in factis...In factis, ut si qui abhorrens aliquid a sanctimonia et nomine suo fecisse dicatur; ut est fabula de adulterio Martis et Veneris (...lo indecoroso tiene su reflejo en las palabras o en los hechos...En los hechos, como cuando se dice que alguien ha hecho algo incompatible con la virtud y el buen nombre: por ejemplo, la fábula relativa al adulterio de Marte y Venus).

16 Etymol., V, 26, 14: Stuprum. Raptus propie est inlicitus coitus, a conrrumpendo dictus; unde et qui «rapto potitur», stupro fruitor (Estupro. En su sentido propio, rapto es una unión ilícita. Deriva de corromper. De ahí que se diga rapto potitur (encuentra placer en el rapto), es decir, disfruta del estupro).

17 Etymol., V, 26, 24: Incesti iudicium in virgines sacratas vel propinquas sanguine constitutum est. Qui enim talibus miscuntur incesti, id est incasti habentur (Delito de incesto es el constituido contra las vírgenes consagradas o contra personas unidas por vínculos de parentesco, mediante relaciones carnales. A quienes mantienen tales relaciones se les llama incestuosos, es decir, no castos); X, I, 148: Incestus, propter inlicitam conmixtionem vocatus, quasi incastus; sicut qui virginem sacram, vel adfinitatis suae proximam stupraverit (Incesto, así llamado por una ilícita relación carnal, como si dijéramos incastus (no casto); es el caso del que comete estupro con una doncella consagrada o con una mujer de su familia).

Textos medievales

Hispania Sacra 55 (2003) 
ción significativa de entradas y definiciones en Etymologiae ${ }^{18}$. En relación a la figura de la prostituta Isidoro no sólo denuncia la inmoralidad del comercio sexual, que avergüenza tanto a aquélla que lo ofrece como al varón que usa de él, sino que además encuentra especial peligro corruptor en estas mujeres, cuya actividad abre la puerta a otros delitos que arrastran a los hombres a la perdición. Caracteriza así a la prostituta por su lascivia y rapacidad, vinculándolas con la mentira y el engaño, e ignorando por completo la miseria y necesidad que con frecuencia se hallan en el origen del ejercicio de esta actividad, en la que la mujer es a menudo utilizada por una autoridad masculina próxima a ella (padre, marido, dueño, en el caso de la prostituta esclava), para obtener provecho de sus ganancias. Tales circunstancias, por el contrario, están bien presentes en la legislación civil, que contempla severos castigos para los padres, maridos o los dueños que dedican a sus hijas o a sus esclavas al comercio carnal, buscando lucrarse del mismo ${ }^{19}$. Estrechamente unido a la actividad de la pros-

18 Etymol., X, F, 110: Fornicarius. Fornicatrix est cuius corpus publicum et vulgare est. Haec sub arcuatis prostrabantur, que loca fornices dicuntur, unde et fornicariae (Fornicarius. Fornicatrix (prostituta), mujer cuyo cuerpo es público y de todos. Solían prostituirse bajo las arcadas, que reciben el nombre de fornices, y de ahí que se las conozca también como fornicariae); X, L, 163: Lupa, meretrix, a rapacitate vocata, quod ad se rapiat miseros et adprehendat (Lupa: meretriz; se la denomina así a causa de su rapacidad, porque arrastra hacia ella a los infelices y los esquilma); X, M, 182: $\mathrm{Me}$ retrix dicta eo quod pretium libidinis mereatur. Inde et meritoriae tabernae (Meretrix (meretriz): se la denomina así porque «merece» el precio que cobra por su lascivia. De ahí también la denominación de las tabernae meritoriae (prostíbulos)...); X, P, 229 Prostitutae, meretrices a prosedendo in meritoriis vel fornicibus. Pelex apud Graecos propie dicitur, a Latinis concuba. Dicta autem a fallacia, is est versutia, subdolositate vel mendacio (Prostitutae: meretrices, término derivado de prosedere (exponerse al público) en prostíbulos y lupanares; los griegos, con propiedad, les aplicaban el nombre de pellex; los latinos dicen concuba (concubina). El nombre deriva de fallacia, es decir, argucia, engaño, mentira); XVIII, 42, 2: Idem vero theatrum, idem et prostibulum, eo quod post ludos exactos meretrices ibi prostrarentur. Idem et lupanar vocatum ab eisdem meretricibus, quae propter vulgati corporis levitatem lupae nuncupabantur: nam lupae meretrices sunt a rapacitate vocatae, quod ad se rapiant miseros et adprehendant. Lupanaria enim a paganis constituta sunt ut pudor mulierum infelicium ibi publicaretur, et ludibridio haberentur tam hi qui facerent quam qui paterentur (Al teatro se le denomina también «prostíbulo», porque, terminado el espectáculo, allí se prostituían (prostrare) las rameras. Se llama también lupanar por estas mismas meretrices, que, a causa de la frivolidad de su prostituido cuerpo, reciben el nombre de lupae (lobas), pues, «lobas» son llamadas las prostitutas por su rapacidad, ya que atraen hacia ellas a los desdichados y los atrapan. Pues los paganos establecieron lupanares para que allí se expusiera al público el pudor de las infelices mujeres y sufriera deshonra tanto los que allí acudían como quienes en aquel lugar se prostituían); XIX, 26, 2: Ludices a ludis, id est theatris, vocatos quidam existimant: quum enim egrediebantur de ludi prostibulo iuvenes, horum velamento tegebant caput et faciem; quia solet erubescere qui lupanar intraverit (Hay quienes opinan que los ludices derivan su nombre de ludus, es decir, del teatro. En efecto, cuando los jóvenes salían del prostíbulo del teatro solían cubrir con esta prenda su cabeza y su rostro; porque normalmente el que entra en un lupanar siente vergüenza).

19 L. V., III, 4, 17: Se castiga a las prostitutas libres con trecientos azotes, además de pérdida de la libertad y expulsión de la ciudad ante la reincidencia. También se castiga con cien azotes a los 
titución presenta Isidoro el mundo del teatro y los espectáculos, que asocia a la Antigüedad pagana, y que condena expresamente por su liberalidad en la representación de los comportamientos sociales relacionados con la sexualidad ${ }^{20}$.

Pero es que además San Isidoro señala que un uso liberal de la sexualidad, no contenido ni dominado, amén de generador de pecados y delitos, es igualmente, en el terreno de las creencias religiosas, distintivo de todos aquellos movimientos que él considera en oposición al cristianismo oficial y su Iglesia, empezando por los cultos paganos y sectas filosóficas de la Antigüedad Clásica, y continuando por distintos grupos heréticos surgidos en el seno de la primitiva Iglesia cristiana. Así, Etymologiae ofrece a menudo una imagen disoluta del pasado grecorromano, época en la que se frecuentaban lupanares y prostíbulos, los teatros y espectáculos ofrecían imágenes de depravación sexual, aspectos ambos a los que ya nos hemos referido, y en la que el panteón religioso estaba encabezado por una divinidad, Júpiter, maestra en todos los crímenes sexuales que el autor ha tipificado, cuales son lujuria, rapto, estupro e incesto, y contenía también otras deidades, como Marte y Venus, que ofrecen un tristemente célebre ejemplo de adulterio ${ }^{21}$. Por ello, señala Isidoro, «resultaba

padres consentidores que viven de lo que ella gana. Las prostitutas siervas reciben similar castigo físico y deben ser alejadas de la ciudad por su señor, bajo amenaza de recibir éste cincuenta azotes si la sierva reincide. Duro es el castigo para los señores que dedican a sus siervas a la prostitución para quedarse con la ganancia, que recibirán trescientos azotes. También se contemplan penas de azotes y pecuniarias para los jueces que por negligencia o soborno no persiguen estos delitos, lo que parece indicar que con frecuencia las autoridades hacían la vista gorda ante estas actividades.

20 Además de los ya citados Etymol., XVIII, 42, 2, y XIX, 26, 2 (cfr. supra nota 18), también Etymol., XVIII, 46: Comoedi sunt qui privatorum hominum acta dictis aut gestu cantabant, atque stupra virginum et amores mereticum in suis fabulis exprimebant (Los comediógrafos son los que, con sus palabras y sus gestos, cantaban hechos de personas particulares y representaban en sus comedias los estupros de las doncellas y los amores de las prostitutas); XVIII, 48: Histriones sunt qui muliebri indumento gestus inpudicarum feminarum exprimebant (Los histriones son los que, vestidos con ropas femeninas, imitaban los gestos de las mujeres impúdica) y XVIII, 51: Et est plane in artibus scenicis Liberi et Veneris patrocinium, quae privata et propia sunt scenae, de gestu et corporis fluxu. Nam mollitiam Libero et Veneri inmolabant, illi per sexum, illi per luxum dissoluti: quae vero ibi vocibus et modis et organis et lyris transiguntur, Apollines et Musas et Minervas et Mercurios patronos habent. Quod spectaculum, Christiane, odere debes, quorum odisti austores (Es de todo punto evidente el patrocinio de Líber y de Venus en las artes escénicas y en todo lo propio y privativo de la escena, como son los gestos y flexiones del cuerpo. En efecto, ofrendaban a Líber y a Venus la sensualidad, unos por el sexo, y otros, disolutos, por el fasto. Por su parte, todo cuanto se desarrolló mediante la palabra y el canto, los instrumentos de viento y las liras, tiene como patronos a los Apolos, las Musas, las Minervas y los Mercurios. Tú, cristiano, debes aborrecer este espectáculo del mismo modo que aborreciste a sus patronos). Todo este capítulo, con ligeras variantes, sigue a TERTULIANO, De Spectaculis, 10, 8-9.

21 Etymol., VIII, 11, 34-35: Iovis fertur a iuvando dictus, et Iuppiter quasi iuvans pater, hoc est, omnibus praestans. Hunc et privato titulo Iovem Optimum dixerunt, dum fuisset incestus in suis, inpudicus in extraneis. Quem modo taurum fingunt propter Europae raptum; fuit enim in navi cuius

Textos medievales

Hispania Sacra 55 (2003) 
infamante creer en tales dioses, a quienes los hombres no deben parecerse», señalando que las conocidas hazañas sexuales de Júpiter «no son simples imágenes literarias, sino crímenes auténticos ${ }^{22}$. Atribuye también excesos sexuales a dos antiguas escuelas filosóficas, los cínicos, a los que acusa de copular en público con sus esposas ${ }^{23}$, y los epicúreos, para los que afirma que el placer corporal es el bien supremo ${ }^{24}$. En cuanto a los grupos sectarios nacidos dentro del primitivo cristianismo, adjudica prácticas contrarias a la moral sexual cristiana a los nicolaítas, cerintianos, adamitas, paternianos y heraclitas ${ }^{25}$, tales

insigne erat taurus: modo Danaes per imbrem aureum appetisse concubitum; ubi intellegitur puditiciam mulieris ab auro fuisse corruptam: modo in similitudine aquilae, ptopter quod puerum ad stuprum rapuerit: modo serpentem, quia reptaverit, et cygnum, quia cantaverit (Se dice que Júpiter deriva su nombre de «ayudar», y que Júpiter viene a significar «el padre que ayuda», es decir, que a todos asiste. Como título particular lo denominaron Júpiter el Óptimo, a pesar de que fue un incestuoso entre los suyos y un lujurioso entre los que no perténecían a su familia. Unas veces lo representan con figura de toro, por el rapto de Europa: en realidad, éste se produjo en una nave cuya enseña era un toro; otras veces, como lluvia de oro, gozando de los encantos de Dánae: donde se da a entender que el pudor de la mujer se vió corrompido por el oro; en ocasiones, bajo la apariencia de un águila, por haber raptado a un joven para cometer estupro con él; en otras ocasiones, como una serpiente, porque se arrastró; o como un cisne porque cantó). Cfr. también supra notas 15, 18 y 20.

22 Etymol., VIII, 11, 36: Et ideo non figurae istae sunt, sed plane de veritate scelera. Unde turpe erat tales deos credi, quales homines esse non debeant.

23 Etymol., VIII, 6, 14: Cynici ab inmunditia inpudentiae nuncupati. Contra humanam enim verecundiam in propatulo coire cum coniugibus eis mos erat, censentes licitum honestumque esse palam cum uxore concumbere, quia coniugium iustum est, publice id praedicantes agendum, ut canes in vicis vel plateis. Unde et a canibus, quorum vitam imitabantur, etiam vocabulum nomenque traxerunt (De la inmundicia de su desvergüenza reciben su nombre los «cínicos». En contra de toda vergüenza humana, tenían costumbre de copular públicamente con sus mujeres, asegurando que es lícito y honesto yacer en público con la esposa, puesto que lícito y honesto es el matrimonio; y predicaban que esto debía hacerse a la vista de todos, como los perros en las calles y plazuelas. Precisamente de los canes, cuya vida imitaban, tomaron su denominación y su nombre).

24 Etymol., VIII, 6, 15: Epicurei dicti ab Epiruro quodam philosopho amatore vanitatis, non sapientiae quem etiam ipsi philosophi porcum nominaverunt, quasi volutans in caeno carnali, voluptatem corporis summum bonum adserens; qui etiam dixit nulla divina providentia instructum esse aut regi mundum (Los epicúreos se llaman así por Epicúreo, un filósofo amante de la vanidad, que no de la sabiduría, a quien los filósofos mismos dieron el calificativo de puerco porque, como revolcándose en el fango de la carne, afirmaba que el placer corporal era el bien supremo; dijo también que el mundo no estaba organizado ni regido por ninguna providencia divina).

25 Etymol., VIII, 5, 5: Nicolaitae dicti a Nicolao, diacono Ecclesiae Hierosolymorum... qui propter pulchritudinem relinquens uxorem, ut qui vellet eam uteretur, versa est in stuprum talis consuetudo, ut invicem coniugia commutarentur (Los nicolaítas deben su nombre a Nicolao, diácono de la Iglesia de Jerusalén, ... abandonó a su mujer a causa de su hermosura, para que quien lo deseara se sirviera de ella; esta costumbre degeneró en lujuria generalizada, de modo que los matrimonios intercambiaban los cónyuges); VIII, 5, 8: Cerinthiani a Cerintho quodam nuncupati. Hi inter cetera circumcisionem observant; mille annos post resurrectionem in voluptate carnis futuros praedicant (De alguien llamado Cerinto recibieron su denominación los cerintianos. Entre otras cosas, observan la práctica de la circuncisión, y predican que, después de la resurrección, se va a estar gozando de las 
como el intercambio sexual de parejas, el nudismo, la circuncisión ${ }^{26}$, y un general apego a las delicias carnales, pero también creencias sexuales equivocadas, como denostar las partes genitales del cuerpo humano, atribuyendo su creación al diablo ${ }^{27}$, o el rechazo del matrimonio y la procreación, aspectos que resultan claramente contrarios a la tradicional concepción cristiana del matrimonio como opción de vida apropiada para el cristiano ${ }^{28}$, único marco legítimo del contacto sexual de hombre y mujer que debe estar siempre abierto a la procreación, en cumplimiento de la naturaleza reproductora con la que Dios dotó al ser humano ${ }^{29}$. Llama la atención el hecho de que las trasgresiones en materia de moral sexual son el argumento único del que se sirve San Isidoro para evidenciar el carácter erróneo y malvado de estos movimientos y sectas, sin entrar en mayores ni más profundos análisis teológicos de sus creencias. El

delicias carnales durante mil años). VIII, 5, 14: Adamiani vocati, quod Adae imitentur nuditatem; unde et nudi orant, et nudi inter se mares feminaeque conveniunt (Reciben el nombre de adamitas los que imitan la desnudez de Adán: desnudos hacen oración, desnudos conviven hombres y mujeres); VIII, 5, 33: Heraclitae ab Heraclio auctore exorti. Monachos tantum recipiunt, coniugia respuunt, regna caelorum parvulos habere non credunt (En Heraclio tienen su origen los heraclitas: únicamente admiten los monjes; rechazan el matrimonio y no creen que los niños puedan entrar en el reino de los cielos); VIII, 5, 58: Paterniani a Paterno quodam exorti [qui] inferiores corporis partes a diabolo dactas opinantur (Los paternianos, nombre que deriva de un cierto Paterno, opinan que las partes más bajas del cuerpo han sido creadas por el diablo);

26 También los concilios hispanovisigodos prohíben a los judíos la celebración del rito de la circuncisión, «abominación»y «afrenta corporal» (iniuria corporis, abobinandas circumcisiones exerce$r e$ ), y la desobediencia se castiga muy duramente, ya que se separa a los niños circuncidados de sus padres, o se otorga la libertad al siervo circuncidado en compensación por la afrenta corporal recibida, cfr. Toledo IV (633 d.C.), 59 y Toledo XII (681 d.C.), 9. Igualmente la legislación civil, en concreto la ley del rey Ervigio contra los judíos, prohíbe la circuncisión bajo penas muy crueles, cuales son la amputación del miembro viril a todo varón que haga esta práctica en sí o en otro, o la mandara hacer, y la amputación de la nariz en la mujer, además de la pérdida del patrimonio, que pasa a manos del rey, y el destierro en ambos casos, cfr. $L$. V., XII, 3, 4.

27 En relación con este aspecto hay que considerar que las autoridades eclesiásticas rechazan cualquier mutilación de los órganos sexuales, de manera que inhabilita para el oficio clerical a todos aquellos que se automutilaron para evitar la concupiscencia carnal y atentaron así contra el cuerpo creado por Dios, y esta misma doctrina mantiene la Iglesia hispanovisigoda, cfr. Braga II (572 d.C.), Item capitula ex orientalium patrum synodis a Martino episcopo ordinata atque collecta aput Lucense concilium, 21; Toledo IV (633 d.C.), 19.

28 De hecho el canon 11 de Braga I (561 d.C.) condena a aquellos que, siguiendo las doctrinas heréticas de maniqueos y priscilianistas, rechazan el matrimonio y la legítima procreación en él como forma de vida válida para un cristiano, en favor de la perpetua abstinencia sexual.

29 Cfr. Toledo III (589 d.C.), 17; L. A. GARCÍA MORENO, «La mujer visigoda entre la represión sexual y el poder político", La mujer en el mundo antiguo, Actas de las V Jornadas de Investigación Interdisciplinaria del Seminario de Estudios de la Mujer de la Universidad Autónoma de Madrid, Madrid, 1986, p.416. Así el mandato divino creced y multiplicaros (Génesis, I, 28). La sexualidad del hombre ha sido creada por Dios, es por tanto parte del ser humano, pero para usarla de forma apropiada, vinculada al legítimo matrimonio y a la procreación en su seno.

Textos medievales

Hispania Sacra 55 (2003) 
desorden del comportamiento sexual se revela así como un argumento con el suficiente peso como para que el autor considere innecesario $\mathrm{u}$ ocioso añadir más detalles sobre las creencias y actitudes desviadas de tales movimientos a ojos de la ortodoxia cristiana. Obtenemos así la impresión de que un comportamiento sexual de la persona acorde con la moral cristiana es prueba de valor muy estimable a la hora de avalar la pureza de su fe.

En definitiva, San Isidoro deja claro que una líbido muy activa, o que se expresa mediante prácticas sexuales contrarias a la moral cristiana, constituye un comportamiento propio de paganos, sectarios y herejes ${ }^{30}$, e incluso de demonios y seres inmundos ${ }^{31}$. Así Etymologiae da buenas pruebas de la condena que para su autor merecen prácticas sexuales como la zoofilia y la sodomía u homosexualidad masculina ${ }^{32}$. Pero San Isidoro también manifiesta, como con-

30 De hecho un aspecto importante a considerar en la represión, por parte de las autoridades eclesiásticas hispanovisigodas, de la excesiva familiaridad con el sexo femenino de un hombre consagrado, es que ese comportamiento puede ser tomado por la autoridad eclesiástica, en determinado contexto, como síntoma de una desviación más profunda en la pureza de su doctrina, es decir, como señal de creencias heréticas, ya que la convivencia estrecha con mujeres, generadora de corrupción y excesos sexuales, es uno de los vicios que los Padres de la Iglesia atribuyen a los líderes de diversas herejías, caso del obispo Prisciliano de Avila, promotor de un movimiento de renovación espiritual considerado herético por las autoridades eclesiásticas hispanorromanas, y todavía arraigado en algunas de sus prácticas entre los grupos populares del Noroeste hispano, a juzgar por los cánones condenatorios que recoge el primer Concilio de Braga en el 561 d.C., que prohíbe y condena, como práctica priscilianista, la convivencia estrecha de clérigos y monjes con mujeres que no sean de su familia. Cfr. SAN JERÓNIMO, Epist., CXXXIII, 4, que presenta una lista de lo que podría considerarse el patronazgo femenino en los movimientos heréticos; R. LÓPEZ CANEDA, Prisciliano. Su pensamiento y su problema histórico, Santiago de Compostela, 1966, pp.66, 84, 147; H. CHADwICK, Prisciliano de Ávila, Madrid, 1978, pp. 62, 8384, 192-193; H. GALlEGO FRANCO, Femina dignissima. Mujer y sociedad en la Hispania antigua, Valladolid, 1991, pp.146-150; Braga I (561 d.C.), 15. También en la carta que el obispo Montano dirige a los palentinos al final de Toledo II (527 d.C.) se acusa a los priscilianistas de excesos sexuales: dice de Prisciliano, «... en él, como en un pozo negro, se amontonaron todos los vicios y cuentan entre sus hazañas el empleo del maleficio para robar, como adúltero impúdico, el pudor de sus sectarias, y alcanzar más fácilmente el objetivo de sus crímenes nefandos» («... omnium vitiorum in eodem congeries veluti in sordium sentina confluxit, ut sectraticum pudorem impuderatus adulter eriperet, et ut ad scelereis nefarii effectum facilius perveniret, maleficii usum gesta eius assignant»).

31 Etymol., VIII, 11, 103: Pilosi, qui Graecae Panitae, Latine Incubi appellantur, sive Inui ab ineundo passim cum animalibus. Unde et Incubi dicuntur ab incumbendo, hoc est stuprando. Saepe enim inprobi existunt etiam mulieribus, et aerum peragunt concubitum: quos daemones Galli Dusios vocant, quia adsidue hanc peragunt inmunditiam (Los «peludos», en griego, se llaman panitas; y en latín, íncubos, o bien inuos, derivado de inire, del trato carnal que acá y allá mantienen con animales. Del mismo modo, los íncubos toman su nombre de incumbere, esto es, de fornicar. A menudo estos desalmados cohabitan también con mujeres, con quienes tienen relación carnal. A estos demonios los galos los llaman «dusios», porque viven continuamente en esta inmundicia).

32 Si bien la zoofilia no recibe una condena expresa en los concilios hispanovisigodos, sin duda era una práctica sexual aborrecida por las autoridades eclesiásticas, ya que en la colección de cánones de los concilios de los primitivos Padres orientales seleccionados por Martín, obispo de Braga, y 
trario a la moral sexual cristiana, el rechazo del legítimo sexo matrimonial destinado a la procreación, mecanismo reproductor que es obra de Dios. Del mismo modo resulta claro que toda actividad sexual que no se ajuste al esquema cristiano de la sexualidad conyugal reproductora se considera lujuria y lascivia, por tanto, fornicación pecaminosa y engendradora de delitos. El matrimonio otorga así al hombre tres grandes beneficios, el primero cumplir con el mandato divino de procrear, el segundo, entregarle una ayuda que se le asemeje (la mujer), y el tercero evitarle caer en el pecado de fornicación, o incluso en algo peor, como las relaciones homosexuales, y es así la mejor opción de vida para aquel cristiano que no puede obviar sus impulsos sexuales ${ }^{33}$. Abierto

expuesta al final del Concilio de Braga II (572 d.C.),el canon 81 recoge precisamente la condena a aquellos que se mezclan con los animales, para los que reserva la humillación pública a la puerta de la iglesia durante decenas de años y larguísimas excomuniones y penitencias. Allí se afirma de aquéllos que se mezclan con animales que «...conviene que éstos oren entre los poseídos por el demonio» («...Oportet enim tales inter daemoniosos orare»). Precisamente San Isidoro de Sevilla en «Las Etimologías» atribuye el ayuntamiento con animales al comportamiento sexual de demonios y seres inmundos, cfr. Etymol., VIII, 11, 103 (cfr. supra nota 31). Igualmente, el rechazo de San Isidoro a los homosexuales y afeminados es claro: Etymol., X, M, 179: Mollis, quod vigorem sexus enerviati corpore dedecoret, et quasi mulier emolliatur (Mollis (afeminado), porque deshonra con su cuerpo lánguido el vigor de su sexo, y porque se muestra blando (emolliri) como una mujer); XI, 2, 19: Sed ideo virtus maxima viri, mulieris minor, ut patiens viri esset; scilicet, ne feminis repugnantibus libido cogeret viros aliud appetere aut in alium sexum proruere (Es mayor en el varón y menor en la mujer la fuerza, para que la mujer pudiera soportarlo, y además no fuera que, al verse rechazado por la mujer, el marido se viera empujado por su concupiscencia a buscar otra cosa o deseara el placer homosexual); XII, 7, 63: Perdix... avis dolosa atque inmunda; nam masculus in masculum insurgit, et obliviscitur sexum libido praeceps (La perdiz... es un ave falaz e inmunda, pues el macho monta al macho y se olvida de su propio sexo, empujado por la lujuria). En la Hispania visigoda la legislación eclesiástica y civil condena la homosexualidad masculina con graves penas. En el canon 3 de Toledo XVI (693 d.C.) el culpable, puesto bajo custodia episcopal, pierde la dignidad eclesiástica si se trata de un clérigo, y sufre destierro perpetuo, excomunión perpetua, salvo que una adecuada penitencia le permita comulgar en el momento de su muerte, y previo a todo ello la vergüenza pública de recibir cien azotes y ser decalvado. También en las reglas monásticas hispanovisigodas aflora la preocupación por las posibles relaciones homosexuales o pederásticas en los monasterios, cfr. L. GARCIA IGLESIAS, «La edad difícil y la sexualidad adolescente en la España visigoda», en HAnt, VI (1976) 91-93; J. IBÁÑEZ ALLER, «Aproximación a la problemática de la sexualidad en las reglas monásticas masculinas hispanovisigodas: las regulae de San Isidoro y San Fructuoso", en Homenaje al Prof. Montenegro, Valladolid, 1999, pp.765-766. La Lex Visigothorum castiga a los homosexuales, tanto al amante como al amado, con la castración y el encierro en lugares de penitencia; sólo queda libre de pena el que se ha visto obligado a cometer el delito por violación; los reos casados pierden la hacienda, que pasará a sus hijos legítimos, y su esposa recupera sus arras y queda libre de volver a casarse, cfr. $L$. $V$., III, 5,5 y 6.

33 Etymol., IX, 7, 27: Tribus autem ob causis ducitur uxor: prima est causa prolis, de qua legitur in Genesi (1, 28): "Et benedixit eos», dicens: "Crescite et multiplicamini»; secunda causa adiutorii, de qua ibi in Genesi dicitur (2, 18): "Non est bonum esse hominem solum; faciamus ei adiutorium simile»; tertia causa incontinentiae, unde dicit Apostulus, ut (1 Cor. 7, 9): "Qui se non continet, nubat» (Tres son los motivos por los que se puede tomar mujer: el primero, para tener descendencia; sobre ello leemos en el Génesis $(1,28)$ : «Y los bendijo, diciéndoles: creced y multiplicaos». El segun-

Textos medievales

Hispania Sacra 55 (2003) 
siempre a la procreación, es indisoluble, y en él el marido ostenta la autoridad sobre la esposa ${ }^{34}$. Incluso enlaza matrimonio y procreación a través de la etimología de «lecho nupcial»: «Hablando con propiedad, lecti geniales (tálamos nupciales) son los que se preparan para los jóvenes recién casados; su nombre deriva de engendrar (generare) hijos» ${ }^{35}$, o a través de la etimología de «familia», al afirmar Isidoro que «familia» son los hijos legítimos y deriva de «fémur», término este último que evoca las partes sexuales ${ }^{36}$. Se considera por lo tanto ilegítima e impura toda descendencia habida fuera del matrimonio, bien sea de padre conocido o desconocido, fruto de la fornicación y el adulterio, el concubinato o el contubernio, niños que se designan como hijos naturales, bastardos o espurios ${ }^{37}$.

do motivo es la ayuda; acerca de esto se dice en el Génesis $(2,18)$ : «No es bueno que el hombre esté solo; proporcionémosle una ayuda que se asemeje». El tercer motivo es la incontinencia, por lo que dice el Apóstol (Pablo) que «el que no tenga el don de la continencia, que se case» $(1$ Cor., 7,9$)$. Sobre el peligro de caer en la homosexualidad si el hombre no pudiera tener relación sexual con la mujer, por ser rechazado, cfr. Etymol., XI, 2, 19 (supra nota 32).

34 Etymol., IX, 7, 9, 20 y 30. A matrimonio se opone adulterio y fornicación: Etymol., IX, 7, 5: Arrabo dicta, quasi arra bona. Quod enim datur pro coniugio, bene datur, quia coniugium bonum est. Quod vero causa fornicationis aut adulterii, malum est, idcirco arrabo non est (Las arras se denominan arrabo, como si dijéramos «arras buenas», pues lo que se da como promesa de matrimonio es bueno, pues bueno es el matrimonio. En cambio, el pago de fornicación o adulterio es malo, y por eso no se denomina $a r r a b o$ ).

35 Etymol., XX, 11, 5: Geniales lecti proprie sunt qui sternuntur puellis nubentibus; dicti autem a generandis liberis.

36 Etymol., IX, 4, 3: Nam familia est liberi ex liberis legibus suscepti, a femore (La familia son los hijos reconocidos según las libres leyes, y su nombre deriva de fémur), cfr. Etymol., XI, 1, 106 : Femora dicta sunt, quod ea parte a fenina sexus viri discrepet. (Los muslos tienen este nombre (femo$r a)$ porque por esta parte se distingue el sexo del varón del de la hembra (femina))

37 Etymol., I, 7, 13: Dicta autem notha, quemadmodum nothus dicitur quisquis de dispari genere nascitur (Si se llaman bastardos es debido a que se dice bastardo al que ha nacido de una unión ilícita); IX, 4, 29: Collegiati dicuntur... qui facinus aliquod commiserunt. Est enim sordidissimum genus hominum patre incerto progenitum (Se llama colegiados a los que han cometido algún delito...Es una ralea de gente envilecida, hijos de padre desconocido); IX, 5, 19: Naturales autem dicuntur ingenuarum concubinarum filii, quos sola natura genuit, non honestas coniugii (Son conocidos como naturales los hijos habidos de concubinas libres, pues solamente los ha engendrado la inclinación natural y no la honestidad del matrimonio); IX, 5, 23-25: Nothus dicitur, qui de patre nobili et de matre ignobili gignitur, sicut ex concubina... Huis contrarius spurius, qui de matre nobili et patre ignobili nascitur. Item spurius patre incerto, matre vidua genitus, velut tantum spurii filius... Eosdem et Favonios appellabant, quia quaedam animalia Favonio spiritu hausto concipere existimantur. Unde et hi, qui non sunt de legitimo matrimonio, matrem potius quam patrem sequuntur. Latine autem spurii quasi extra puritatem, id est quasi inmundi (Se denomina nothus (bastardo) al nacido de padre noble y de madre plebeya, por ejemplo de una concubina... Es hijo espurio el que nace de madre noble y padre plebeyo. Se dice también espurio cuando es de padre desconocido y de madre viuda, como si solamente hubiera intervenido en su concepción la mujer... Se les aplica también el nombre de favonios, porque se creía que algunos animales quedan preñados por el soplo ardiente del viento favonio. De ahí que los que no provienen de un legítimo matrimonio, sigan a la madre más bien que al padre. En latín «espu- 
Sin embargo, San Isidoro ahonda aún más en esta imagen negativa del deseo sexual al apuntar que un ejercicio desinhibido de la sexualidad no sólo arruina la salud moral y espiritual de la persona, abriéndole las puertas del pecado y el delito, sino que puede también destruir su salud física y financiera, daños estos ciertamente no menos preocupantes para el lector. Afirma así que el exceso de práctica sexual resulta muy negativo para la salud: «Lujurioso es el que apetece, no el alimento necesario, sino comidas suntuosas y caras, ávido de placeres e inclinado a la lascivia», y «La consecuencia de todo exceso no es salud, sino el peligro de la misma» ${ }^{38}$. En otro punto señala: «Macer (delgado) deriva de macies (delgadez); y macies, por su parte, deriva de moechia (concubinato), porque una actividad sexual inmoderada produce delgadez» ${ }^{39}$. Incluso una explícita manifestación física del deseo en los órganos sexuales masculinos es considerada síntoma de una enfermedad: así, en sus párrafos sobre las enfermedades crónicas, aquellas que duran mucho tiempo y provienen de los humores flema y melancolía, sitúa la satiriasis o priapismo, que define como «el deseo de relación sexual acompañado de abultamiento de las partes genitales. Este mal recibe el nombre de los sátiros $»^{40}$. Igualmente una actividad sexual inmoderada es también nociva para la hacienda y el patrimonio propio y familiar: «El nombre de nepos (manirroto) tiene su origen en una especie de escorpiones que devora a sus crías, excepto a una que se encarama a sus espaldas; y precisamente el que se ha salvado termina por devorar al padre. De ahí que los hombres que, en su libertinaje, despilfarran la hacienda paterna, reciben el calificativo de nepotes. Por eso también se suele emplear el término nepotatio con el valor de lujuria, porque ésta, a la verdad, consume muchos patrimonios ${ }^{41}$.

En definitiva, el deseo sexual se concibe como un evidente peligro para el ser humano, cuyo ejercicio al margen de la estrecha senda dibujada por la moral cristiana sitúa al hombre al borde del precipicio de la ruina moral, espiri-

rios» viene a ser como « sin pureza», es decir, algo así como «inmundos»). Etymol., IX, 7, 23: Contubernium est ad tempus coeundi conventio; unde et tabernaculum, quod modo huc, modo illuc praefigitur (Contubernio es el acuerdo de cohabitar durante un período determinado de tiempo; de la misma raíz es «tabernáculo», que un día se establece aquí y otro día en otro lugar).

38 Etymol., II, 29, 5: ... Luxuriosus est victus non necessarii, sed sumptuosi et onerosi appetens, in deliciis adfluens, in libidine promptus.; IV, 2: ... Inmoderatio enim omnis non salutem, sed periculum effert.

39 Etymol., X, M, 180: Macer, a macie; et macies a moechia, eo quod inmoderata libido macros faciat.

40 Etymol., IV, 7, 34: Satiriasis inge desiderium Veneris cum extensione naturalium locorum. Dicta passio a Satyris.

41 Etymol., X, N, 193: Nepos dictus a genere quodam scorpionum qui natos suos servatus fuerit consumit patrem: unde homines qui boba parentum per luxuriam consumunt nepotes dicuntur. Hinc quoque nepotatio pro luxuria ponitur, qua certe quaeque res consumuntur. No podemos dejar de observar el impactante y plástico efecto en los posibles lectores de la imagen dibujada aquí por Isidoro, que liga la lujuria que devora los patrimonios con el escorpión que devora a sus crías y a su vez es devorado por ellas.

Textos medievales

Hispania Sacra 55 (2003) 
tual, física y financiera. Igualmente, el sexo aparece como algo sucio en si mismo, de manera que San Isidoro califica las referencias en el lenguaje, más o menos explícitas, al sexo y a cuestiones con él relacionadas, como repugnantes y obscenas, y recomienda que, incluso al hablar de las relaciones carnales entre esposos, hay que tratar la cuestión sexual con toda la decencia posible en el lenguaje: «La perífrasis es un circunloquio, cuando se expresa una cosa con varias palabras... Con un rodeo evita lo repugnante; así en (Virg., En., 8, 405) «Acurrucado en el regazo de su esposa, buscó la placidez del sueño». Con este circunloquio evita la obscenidad y muestra con toda decencia la unión carnal» ${ }^{42}$, pero eso sí, sin perder claridad ni caer en lo rebuscado y artificial: «También en las palabras deben evitarse los vicios, de manera que no se empleen palabras impropias... Hay que buscar la propiedad, y aunque en ocasiones, por la bajeza de un vocablo sórdido u obsceno, se empleen palabras de significado translativo, se hará de modo que no den la impresión de ser remotas, sino parientes próximas de la verdadera» ${ }^{43}$. Ciertámente, esta es la máxima que sigue Isidoro, como evidencia el estilo claro y preciso de sus referencias a cuestiones sexuales, véase, por ejemplo, su definición del coito en relación con Venus/Afrodita, la diosa grecorromana del amor y el sexo: «los griegos le dan el nombre de Afrodita, porque tuvo su origen en una espuma de sangre... Cuentan que Saturno castró a su padre, el Cielo, y su sangre fue a parar al mar, y que de la espuma levantada del mar nació Venus; y dicen esto porque mediante el coito se produce la eyaculación de un humor salado, y de ahí que a Afrodita se la llame Venus, porque el coito es espuma de sangre, que consta de una secreción líquida y salada que emana de las vísceras» ${ }^{44}$.

La conclusión inexorable de todos estos razonamientos precedentes es que hay que reprimir el deseo sexual ${ }^{45}$, contenerlo y canalizarlo hacia la legítima

\footnotetext{
42 Etymol., I, 37, 15: Periphrasis est circumloquium, dum res una plurimis verbis significatur... Foeditatem circuitu devitat, sicut (Virg. Aen. 8,405): Placitumque petivit coniugis infusus gremio. Hoc enim circuitu evitat obscenitatem et decenter ostendit concubitum. Esta idea también en Etymol., I, 34, 5: Cacemphaton dictio obscena vel inconposite sonans. Obscena, ut (Virg. Aen. 1,579) His animum arrecti dictis (Cacenphaton es una expresión sucia y sin armonía. Sucia, como, por ejemplo, «excitado el ánimo con estas palabras» (Virg., En. 1,579)).

43 Etymol., II, 20, 1: In verbis quoque cavenda sunt vitia, ut non inpropia verba ponantur... Amanda est ergo proprietas, sic tamen ut aliquando propter humilitatem sordidi aut spurci vocabuli translatis nominibus sit utendum, non tamen longe accitis, sed ut veris proxima et cognata videantur.

44 Etymol., VIII, 11, 76-77: Hanc Graeci 'A $\varphi \rho$ o $\eta v$ vocant propter spuman sanguinis generantem... Quod autem fingunt Saturnum Caelo patri genitalia abscidisse, et sanguinem fluxisse in mare, atque eo spuma maris concreta Venus nata est, illud aiunt quod per coitum salsi humoris subs-

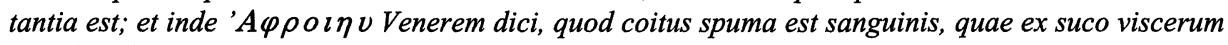
liquido salsoque constat.

45 Lo contrario, la lujuria y la lascivia, es el resultado de «liberar» las pasiones, y no «atarlas», cfr. Etymol., X, L, 160: Libidinosus, ab eo quod facit quod libet.. ... Luxuriosus, quasi solutus in 
reproducción en el seno del matrimonio, o bien abstenerse de la sexualidad en una vida de castidad y celibato consagrada al servicio de Dios y de su Igle$\mathrm{sia}^{46}$. La exaltación de esta segunda opción de vida cristiana resulta evidente en el autor al afirmar: «Caelebs (célibe), el que no está casado, como son los bienaventurados del cielo, ajenos al matrimonio, y se dice caelebs como si dijéramos caelo beatus (bendito del cielo)» ${ }^{47}$. Son igualmente consideradas «puras»o «sin corrupción» las edades del hombre ajenas a la procreación y en consecuencia al sexo, es decir la niñez y la vejez, ésta última especialmente tranquila, pues libera definitivamente de la tiranía de la líbido ${ }^{48}$. Por lo demás, aconseja desde la juventud huir de los excesos de la comida y la bebida, en especial vincula el vino a la pasión sexual, que son elementos provocadores de la lujuria ${ }^{49}, \mathrm{y}$ deben tener en cuenta este consejo sobre todo las

voluptate: unde et membra loco mota luxa dicuntur. Lascivus, quod sit laxus, is est solutus et vanus (Libidinosus (libidinoso), que hace lo que le viene en gana....Luxuriosus (lujurioso), como si dijéramos «desatado» (solutus) en sus pasiones: de ahí viene el que a los miembros salidos de su sitio se les aplique el nombre de «luxaciones» (luxa). Lascivus (lascivo), que está fuera de su lugar, esto es, desatado y vano).

46 Etymol., X, C, 33: Castus primum a castratione nuncupatus: postea placuit veteribus etiam eos sic nominari qui perpetuam libidinis abstinentiam pollicebantur (En un primer momento se denominó casto a los «castrados»; más tarde pareció oportuno a nuestros antepasados aplicar este nombre a los que habían hecho promesa de mantener perpetua abstinencia sexual).

47 Etymol., X, C, 34: Caelebs, conubii expers qualia sunt numina in caelo, quae absque coniugiis sunt. Et caelebs dictus quasi caelo beatus.

48 Etymol., XI, 2, 3: Secunda aetas pueritia, id est pura et necdum ad generandum apta, tendens usque ad quartumdecimum annum (La segunda es la niñez (pueritia), o etapa «pura» y aún no apta para la procreación; abarca hasta los catorce años). En la misma línea XI, 2, 21: Virgo a viridiori aetate dicta est, sicut et virga, sicut et vitula. Alias ab incorruptione, quasi virago, quod ignoret femineam passionem (El nombre de virgen le viene de su muy tierna (viridior) edad, lo mismo que virga (vara) y vitula (ternera). Según otros, de que no conoce aún la corrupción, como si se dijera virago (heroína), porque ignora aún la pasión femenina); XI, 2, 30: Senectus autem multa secum et bona adfert et mala. Bona, quia nos ab inpotentissimis dominis liberat, voluptatibus inponit modum, libidinis frangit impetus, auget sapientiam, dat maturiora consilia (La senectud trae consigo muchas cosas, buenas y malas. Decimos buenas porque nos libera de tiránicos señores, impone un límite a los placeres, debilita la violencia de la líbido, aumenta la sabiduría, proporciona consejos más maduros).

49 Etymol., I, 37, 9: Item per inventorem id, quod inventum est, ut (Ter. Eun. 732): «Sine Cerere et Libero friget Venus»; ... Vult enim per Cererem frumenti inventricem intellegere panem, per Liberum inventorem vitis vinum, per Venerem libidinem (Otro recurso consiste en tomar el invento por el inventor, como en (TER., Eun. 732): «Sin Ceres ni Líber, se enfría Venus... Por Ceres, descubridora del trigo, quiere significar el pan; por Líber, padre de la vid, el vino; por Venus, la pasión). X, C, 35: Continens non solum in castitate dicitur, sed et in cibo et potu, in ira quoque et vexatione mentis et detrahendi libidine. Et continens, quod se a multis malis abstineat (Continente se dice no sólo hablando de la castidad, sino también del que se «contiene» en la comida y en la bebida, así como también el que reprime su ira, conteniendo la violencia de su espíritu y la sensualidad. Es «continente», por lo tanto, el que se abstiene de muchos males). VIII, 11, 43: Liberum a liberamento appellatum volunt, quod quasi mares in coeundo per eius beneficium emissis seminibus liberentur; quod idem Liber muliebri et delicato corpore pingitur. Dicunt enim mulieres ei adtributas et vinum propter excitandam

Textos medievales

Hispania Sacra 55 (2003) 
mujeres $^{50}$, a las que San Isidoro atribuye una naturaleza libidinosa per se: «Femina deriva su denominación de las partes de los muslos, femur, en que su sexo se distingue del de el varón. Otros creen que la etimología es griega, haciendo derivar el nombre de femina de la fuerza del fuego, porque su concupiscencia es muy apasionada: se afirma que las hembras son más libidinosas que los hombres tanto entre las mujeres como entre los animales. Por ello, entre los antiguos, un amor ardiente se llamaba amor femíneo» ${ }^{51}$. Así, la propia mujer se convierte para el hombre en un peligro, ya que es un elemento que incita a la lujuria ${ }^{52}$. Tal razonamiento presta sin duda soporte ideológico a la realidad legislativa de que en la Lex Visigothorum los delitos de adulterio y fornicación parten siempre de la situación creada por la transgresión femenina, que supone un atentado contra la autoridad marital, o contra la moral social y el honor familiar, y aunque normalmente son reos del delito tanto la mujer como su cómplice masculino, no parece despertar la misma inquietud legisladora el adulterio o la fornicación masculina ${ }^{53}$. Igualmente la falta de castidad

libidinem (Pretenden que el nombre de Líber deriva de «liberación», como si los varones, al eyacular durante la cópula, se vieran liberados gracias a él. Se le suele pintar con un delicado cuerpo de mujer, pues dicen que son atributos suyos las mujeres y el vino, porque excitan la lujuria), de manera que resulta así que el vino da a los hombres la misma sensación de libertad que obtienen al eyacular en la cópula, situación esta que para San Isidoro además se ve propiciada con el consumo de esta bebida.

50 Etymol., XX, 3, 2: Unde et Hieronymus in libro quem De virginitate servanda scripsit: "Adolescentulas» inquit Aita vinum debere fugere ut venenum, ne pro aetatis calore ferventi bibant et pereant». Inde est quod apud veteres Romanos feminae non utebantur vinum, nisi sacrorum causa certis diebus (Por esto Jerónimo, en el libro que compuso Sobre la necesidad de conservar la virginidad, escribió: «Las jóvenes deben huir del vino tanto como del veneno, no vaya a ser que, por la ardorosa fogosidad de su edad, beban y perezcan». Por esto, entre los antiguos romanos, las mujeres no probaban el vino, a no ser algunos días muy determinados y por motivos religiosos). Se refiere a San Jerónimo, Epist. 22 ad Eustochinam, Paulae filiam (De custodienda virginitate), 7, 8 = PL 22, 398-399.

51 Etymol., XI, 2, 24: Femina vero a partibus femorum dicta, ubi sexus species a viro distinguitur. Alii Graeca etymologia feminam ab ignea vi dictam putant, quia vehementer concupiscit. Libidinosiores enim viris feminas esse tam in mulieribus quam in animalibus. Unde nimius amor apud antiquos femineus vocabatur. La misma idea subyace en Etymol., XI, 2, 21: Virgo a viridiori aetate dicta est, sicut et virga, sicut et vitula. Alias ab incorruptione, quasi virago, quod ignoret femineam passionem (El nombre de virgen le viene de su muy tierna (viridior) edad, lo mismo que virga (vara) y vitula (ternera). Según otros, de que no conoce aún la corrupción, como si se dijera virago (heroína), porque ignora aún la pasión femenina).

52 Además de Etymol, VIII, 11, 43, donde se asocia claramente mujer y lujuria (cfr. supra nota 49), también Etymol., X, L, 160: Libidinosus a Libero, qui puellarum [corpore pingitur] (Libidinosus deriva de Líber. Quien [es representado con cuerpo] de muchacha); IX, 3, 44: Castra sunt ubi miles steterit. Dicta autem castra quasi casta, vel quod illic castraretur libido. Nam numquam his intererat mulier (Campamento es el lugar de residencia del soldado. Se dice castra, que viene a ser como «casta»; o tal vez porque allí se «castra» la lujuria, pues nunca se encuentra en ellos mujer alguna)

53 L. A. GARCÍA MORENO, «La mujer visigoda entre la represión sexual y el poder político», en La mujer en el mundo antiguo, Actas de las V Jornadas de Investigación Interdisciplinaria del Seminario de Estudios de la Mujer de la Universidad Autónoma de Madrid, Madrid, 1986, pp. 418-419. 
en la mujer, antes, durante o después del matrimonio recibe sanciones en sus derechos a la herencia y sucesión de sus padres y hermanos o de su marido ${ }^{54}$. Es cierto también que el legislador civil se ocupa con exhaustividad del rapto y la violación de la mujer libre, en cualquiera de los estados que le son propios (virgen, prometida/casada, viuda), y de la sierva o esclava, pero más que la preocupación por la mujer agredida, trasciende el interés por satisfacer el daño infligido al honor familiar o a los derechos del padre sobre la hija y del dueño sobre la esclava ${ }^{55}$. En esta auténtica muralla que la legislación civil hispanovisigoda construye en torno a la castidad femenina, para su protección, hasta los médicos no pueden visitar y tratar profesionalmente a una mujer libre si no se halla presente junto a ella alguno de sus parientes ${ }^{56}$. Resulta así que el control del ejercicio de la sexualidad y la represión de la libre disposición del cuerpo de hombres y mujeres ejercido por las autoridades eclesiásticas y civiles en la sociedad hispanovisigoda causa efecto especialmente en el sector femenino de la comunidad, ya que en la defensa de la castidad como valor social hallamos que la mujer juega un papel crucial, porque el mantenimiento de su virtud no sólo la salva a ella del pecado, en la esfera religiosa, o del delito en la esfera civil, sino que salva del pecado y el delito a toda la comunidad, varones incluídos.

Otro aspecto que, en relación a la cuestión sexual, aflora en Etymologiae es la distinta concepción de la sexualidad masculina y femenina. La sexualidad del varón se presenta como básicamente activa, él es el engendrador, de manera que, aunque sus órganos sexuales se tachan de feos y vergonzosos, y por ello se ocultan bajo el vestido, son, en todo caso, su seña de identidad, la esencia de su ser, que es engendrar hijos: «Como su mismo nombre indica, las partes genitales se denominaron así porque engendran hijos, es decir, porque con ellas se procrea y se da vida. Se las conoce también como partes pudentas, a causa de la vergüenza, o por el vello púbico; y por eso se ocultan con un vestido. Se las denomina igualmente partes deshonestas, porque no tienen una apariencia hermosa como miembros colocados en un lugar bien visible. Se les aplica también el nombre de veretrum, porque es privativo del hombre (vir), o porque por él se eyacula el semen (virus). Propiamente virus se denomina al líquido seminal que fluye del varón ${ }^{57}$. La sexualidad de la mujer, en cambio,

54 P. D. KING, Derecho y sociedad en le reino visigodo, Madrid, 1981 (1972), pp.264-266.

55 Ibidem, pp. 268-269.

56 L. $V$., XI, 1,1 , aunque si el dolor de la enferma fuera insoportable y no fuese posible hallar familiar alguno, se permite recurrir a la presencia de algún vecino de probada virtud, o incluso de sus siervos o sus siervas. Cfr. C. PETIT, «Lex Visigothorum 11,1: De medicis et egrotis», Cuadernos de Historia de España, 67-68 (1982) 12-14.

57 Etymol., XI, 1, 102-103: Genitalia corporis partes, ut nomen ipsud docet, gignendae sobolis acceperunt vocabulum, quod is procreator et gignitur. Haec et pudenda pro verecundia, sive a pube: unde et indumento operiuntur. Dicuntur autem ista et inhonesta, quia non habent eam speciem deco-

Textos medievales

Hispania Sacra 55 (2003) 
es entendida por Isidoro curiosamente como pasiva, a pesar de que antes se ha subrayado la líbido fogosa con la que dota a todas las hembras ${ }^{58}$, de manera que tiene su seña de identidad en la maternidad, donde su papel es el de útero receptor del semen, que contiene la potencia engendradora del hombre, y cuya transformación en la matriz da lugar al nuevo ser humano: «El padre es el que da inicio a una familia. Por eso suele llamársele paterfamilias. Y se le denomina «padre» porque, realizado el coito, engendra hijos. Coito (patratio) es la consumación del acto carnal..... Progenitores deriva de «engendrar»; y se les denomina también parentes, «los que paren». Se les llama asimismo creadores, pues crementum es el semen del macho, a partir del cual se conciben los cuerpos de los animales y de las personas. Por ello los padres reciben el apelativo de «creadores». Se dice «madre» porque de ella procede algo. Mater viene a equivaler a materia; el padre, en cambio, es la causa ${ }^{59}$. Obsérvese además

ris sicut membra quae in promptu locata sunt. Idem et veretrum, quia viri est tantum, sive quod ex eo virus emittitur. Nam virus proprie dicitur humor fluens a natura viri.

58 Este concepto pasivo de la sexualidad femenina se refleja también en el hecho de que las únicas prácticas homosexuales que se contemplan en Etymologiae son las masculinas, ignorándose por completo la posibilidad de relaciones homosexuales entre mujeres. Del mismo modo, los cánones de los concilios hispanovisigodos y la Lex Visigothorum sólo se refieren, en su condena y castigo, a la homosexualidad masculina o sodomía, cfr. supra nota 32.

59 Etymol., IX, 5, 3-6: Pater est, a quo initium nascitur generis. Itaque is paterfamilias vocitatur. Pater autem dictus eo quod patratione peracta filium procreet. Patratio enim est rei veneriae consummatio.... Genitores autem a gignendo; et parentes quasi parientes. Idem et creatores. Crementum enim est semen masculi, unde animalium et hominum corpora concipiuntur. Hinc creatores parentes dicuntur. Mater dicitur, quod exinde efficiatur aliquid. Mater enim quasi materia; nam causa pater est. La idea de que el principio activo en la concepción de un nuevo ser es el semen del macho y la hembra y su matriz son receptoras se explicita en otro puntos de Etymologiae: IX, 6, 4-7: Consanguinei vocati, eo quod ex uno sanguine, id est ex uno patris semine sati sunt... Fratres dicti, eo quod sint ex eodem fructu, id est ex eodem semine nati. Germani vero de eadem genetrice manantes; non, ut multi dicunt, de eodem germine, qui tantum fratres vocantur. Ergo fratres ex eodem fructu, germani ex eadem genetrice manantes. Uterini vocati, quod sint ex diversis patribus, et uno utero editi. Nam uterus tantum mulieris est (El nombre de consanguíneos se debe a que son de una misma sangre, es decir, que han sido concebidos del semen del mismo padre...El nombre de fratres (hermanos) se debe a que proceden del mismo fruto; es decir, que han nacido de la misma semilla. El vocablo germani (hermanos) se aplica a los que provienen de la misma madre; y no, como muchos afirman, de la misma semilla germinadora, que entonces se llaman simplemente fratres. Resumiendo: los fratres proceden del mismo «fruto»; los germani provienen de la misma madre. Se llama hermanos uterinos a los que tienen un padre distinto, pero el vientre que los engendró es el mismo: el útero pertenece solamente a la mujer); XI, 1, 15: Crementum enim semen est masculi, unde animalium et hominum corpora concipiuntur. Hinc et parentes creatores vocantur ( $\mathrm{Al}$ semen del macho se lo denomina crementum, pues a partir de él se conciben los cuerpos de los animales y de los hombres. Por esto mismo, a los padres se los llama creadores); XI, 1, 134-137: Uterum solae mulieres habent, in quo concipiunt.....Matrix dicitur, quod foetus in eo generetur: semen enim receptum confovet, confotum corporat, corporatum in membra distinguit. Vulva vocata quasi valva, id est ianua ventris, vel quod semen recipiat, vel quod ex ea foetus procedat (El útero es propio de las mujeres; es en él donde conci- 
con cuanta sutileza vincula sexo matrimonial y maternidad, como los dos momentos dolorosos y esenciales que configuran la vida sexual femenina, en la siguiente cita: «El nombre de Juno viene a querer decir «jano», es decir, puerta, para alivio de las mujeres, porque abre, por así decirlo, a los que nacen, las puertas de sus madres, y al marido, las de la recién casada» ${ }^{60}$.

Otro aspecto, sin duda inquietante, es el papel protagonista que San Isidoro otorga a la fuerza del varón en las relaciones sexuales con la mujer, $\mathrm{y}$, de hecho, su concepción de la diferencia básica entre varón y mujer se centra en el desigual reparto de la fuerza entre ellos, de manera que la debilidad natural de la mujer resulta ser providente para que ésta pueda soportar al hombre sin rebelarse, supeditación por la fuerza de la mujer al varón que, en consecuencia, exporta también a las relaciones sexuales: «El nombre de varón (vir) se explica porque en él hay mayor fuerza (vis) que en la mujer; de aquí deriva también el nombre de «virtud» $\rangle^{61}$; o tal vez porque obliga a la mujer por la fuerza. La mujer, mulier, deriva su denominación de mollities, dulzura, como si dijéramos mollier... La diferencia entre el hombre y la mujer radica en la fuerza y en la debilidad de su cuerpo. Es mayor en el varón y menor en la mujer la fuerza, para que la mujer pudiera soportarlo, y además, no fuera que, al verse rechazado por la mujer, el marido se viera empujado por su concupiscencia a buscar otra cosa o deseara el placer homosexual ${ }^{62}$. San Isidoro expresa, por tanto, que es la mayor fuerza del varón la que hace viable la relación sexual, ya que así la mujer no puede resistirse, y, por extensión, ello posibilita que el varón imponga su autoridad a la mujer ${ }^{63}$. La misma relación entre sexo y fuerza ex-

\footnotetext{
ben.....La matriz se llama así porque en ella se engendra el feto: incuba el semen que ha recibido; una vez incubado, le da cuerpo; después de dotarlo de cuerpo, diferencia sus distintos miembros. Denominamos a la vulva así, como si dijéramos valva, es decir, puerta del vientre, porque recibe el semen, o porque de ella procede el feto); XI, 1, 139-143: Semen est quod iactum sumitur aut a terra aut ab utero ad gignendum vel fructus vel foetus.... eiectusque per coitum, et in utero mulieris susceptus calore quodammodo viscerum et menstrualis sanguinis inrigatione formatur in corpore (Semen es lo que, arrojado, es asimilado por la tierra o por el útero para engendrar el fruto o el feto, respectivamente...... es eyaculado mediante el coito, y, recibido en el útero de la mujer, va tomando forma de cuerpo gracias al especial calor de las vísceras y a la irrigación de la sangre mestrual).

60 Etymol., VIII, 11, 69: Iunonem dicunt quasi ianonem, id est ianuam, pro purgationibus feminarrum, eo quod quasi portas matrum natorum pandat, et nubentum maritis.

61 Es tentador concluir, por tanto, que en el hombre es más propenso a la virtud que la mujer.

62 Etymol., XI, 2, 17-19

63 Etymol., IX, 7, 30: Ideo autem feminae sub viri potestate consistunt, quia levitate animi plerumque decipiuntur. Unde et aequum erat eas viri auctoritate reprimi. Proinde et veteres voluerunt feminas innuptas, quamvis perfectae aetatis essent, propter ipsam animi levitatem in tutela consistere (Las mujeres se encuentran bajo la potestad del varón, porque suelen ser frecuentemente engañadas por la ligereza de su espíritu. De ahí que resultara justo que se vieran gobernadas por la autoridad del hombre. Por eso los antiguos establecieron que las solteras, aún mayores de edad, estuvieran bajo tutela precisamente por la versatilidad de su espíritu). En definitiva, y aunque Isidoro no refleje co-
}

Textos medievales

Hispania Sacra 55 (2003) 
presa en: «Dicen que Venus se llama así porque una virgen sólo deja de serlo cuando se recurre a la fuerza $)^{64}$, que da sin duda una imagen de la penetración como un momento de violencia ${ }^{65}$.

Ciertamente que las creencias e interpretaciones erróneas, cuando no ignorancia absoluta, del funcionamiento del ciclo menstrual de la mujer, así como de los mecanismos de la fecundación y desarrollo del feto, o de la producción del semen en el hombre ${ }^{66}$, por parte del saber científico de la época, no contribuían a modificar esta mentalidad social acerca del papel jugado por la mujer en todo el proceso reproductor humano, así como del funcionamiento de su sexualidad y fertilidad. En consecuencia también en Etymologiae tienen cabida supersticiones y creencias fantasiosas, pero sin duda populares, en relación a ciertos aspectos relacionados con la sexualidad. Es el hecho, por ejemplo, de atribuir efectos perniciosos, incluso corrosivos, a la sangre menstrual de la mujer, de manera que a su contacto los frutos no germinan, el mosto se agria, se secan las hierbas, los árboles pierden el fruto, el hierro pierde su resistencia, el bronce se vuelve negro, se disuelve el betún asfáltico, e incluso los perros que comen algo que ha estado en contacto con ella se vuelven rabiosos ${ }^{67}$. Otra creencia cuanto menos peculiar es la de que la hermosura del fruto concebido por las hembras de animales, y también por la mujer, depende de la belleza de las imágenes que éstas contemplen durante el coito: «De aquí que algunos prohíban a sus mujeres encintas la contemplación de animales de rostro feísi-

\footnotetext{
rrectamente la institución romana de la tutela mulieris, que afectaba en principio tanto a las ciudadanas solteras como a las casadas, hallamos con nitidez en Etymologiae los viejos conceptos de imbecillitas (debilitad) et infirmitas (volubilidad) feminarum que sostienen en la mentalidad grecorromana la supeditación jurídica y social de la mujer a una autoridad masculina, cfr. SÉNECA, De Const Sap., I, 1; Tito Livio, XXXIV, 3; Juvenal, Sat., VI; CATUlo, Carm., LXX; A. DEl CASTIllo, La emancipación de la mujer romana en el siglo I d.C., Granada, 1976, pp.39-40, 130-133; S.B. POMEROY, Diosas, Rameras, Esposas y Esclavas, Madrid, 1987, p.172. Entre los Padres de la Iglesia occidental ya San Jerónimo en la segunda mitad del s.IV d. C. afirmaba que la mujer es un ser débil física y moralmente frente al hombre, que es símbolo de fuerza, y a quien debe someterse en busca de defensa (JERÓNIMO, Epist., 79, 8). Resulta también interesante el hecho de que San Isidoro llegue a contemplar una eventual rebelión de la mujer frente a su destino, circunstancia que para él su debilidad física hace inviable, y que nos recuerda a la lúgubre imagen que de la vida matrimonial femenina pinta de nuevo San Jerónimo (Epist., 22, 2), en su deseo de exaltar la vida cristiana de virginidad, afirmando que la mujer, convertida por las nupcias en esclava, pierde su libertad, y tendrá que soportar la hinchazón de su vientre, el cuidado de la casa, el llanto de los niños pequeños y sentir el tormento de la amiga de su marido.

64 Etymol., VIII, 11, 76: Venerem exinde dicunt nuncupatam, quos sine vi femina virgo esse non desinat.

65 Etymol., IX, 7, 22 muestra el conocimiento de la existencia del himen como membrana que defiende la virginidad: ... quae membrana virginitatis est claustrum.

66 Cfr. Etymol., XI, 1, 97, 134-145.

67 Etymol., XI, 1, 141.
} 
mo, como pueden ser los cinocéfalos y los monos, para que por la impresión de su vista no vayan a dar a luz hijos de aspecto semejante. Y es que la naturaleza de las hembras es tal que, según lo que contemplaron o imaginaron en el último momento de su agitación voluptuosa mientras están concibiendo, así será también su retoño. $\mathrm{Y}$ es que durante el coito el animal transmite a su interior las formas que capta del exterior, y, saturada de imágenes, aprovecha el aspecto de lo que es adaptable a su personal naturaleza» ${ }^{68}$. Sin duda creencias como éstas dotaban a la sexualidad femenina de un halo de misterio e irracionalidad en la mentalidad social de la época. También encontramos originales concepciones sobre los mecanismos del placer sexual: «Los lomos (parte inferior de la espalda) son denominados lumbi por la lascivia de la líbido, ya que en los varones se encuentra en ese lugar la causa del placer sensual, lo mismo que en las mujeres se sitúa en el ombligo. Por eso se dijo a Job en el comienzo de las palabras que Dios le dirigió $(38,3)$ : «Ciñe tus lomos como varón», para que se dispusiera a resistir en ellos que es donde suele presentarse la oportunidad de dominar la lascivia», y «En el hígado residen la líbido y la concupiscencia, al decir de los médicos que disputan de estos temas ${ }^{69}$, así como referencias a la existencia de fantásticos seres-prodigio de sexualidad bipolar, como son los andróginos y hermafroditas: «Los hay, en fin, que presentan mezcla de sexo, como los andróginos y los hermafroditas. Se denomina así a los hermafroditas porque en ellos se muestra uno y otro sexo... Estos tienen el pecho de la parte derecha característico de hombre, y el de la izquierda como el de las mujeres, y pueden fecundar y parir ${ }^{70}$.

Finalmente, en Etymologiae Isidoro hace emerger la naturaleza como un inmenso ser viviente y sexuado. De hecho pone de relieve la semejanza en la forma de varios frutos y plantas con las partes genitales humanas, en especial con los testículos: así la castaña, las aceitunas orchas, el incienso, el orchis o

68 Etymol., XII, 1, 60: Inde est quod quidam gravidas mulieres iubent nullos intueri turpissimos animalium vultus, ut cynocephalos et simios, ne visibus ocurrentes similes foetus pariant. Hanc enim feminarum esse naturam ut quales perspexerint sive mente concepetint in extremo voluptatis aestu, dum concipiunt, talem et sobolem procreent. Etenim animal in uso Venerio formas extrinsecus intus transmittit, eorumque satiata typis rapit species eorum in propiam qualitatem. Sobre los cynocéfalos, con cabeza de perro y oriundos de la India, cfr. Etymol., XI, 3, 12 y 15. También se recogen antiguos prodigios y portentos, como mujeres que dan a luz a serpientes o terneros, cfr. Etymol., XI, 3, 6 y 9.

69 Etymol., XI, 1, 98: Lumbi ob libidinis lasciviam dicti, quia in viris causa corporeae voluptatis in ipsis est, sicut in umbilico feminis. Unde et ad Iob in exordio sermonis dictum est (38, 3): "Accinge sicut vir lumbos tuos»: ut in his esset resistendi praeparatio, in quibus libidinis est usitata dominandi occasio; $\mathrm{XI}, 1,125$ : In iecore autem consistit voluptas et concupiscentia iuxta eos qui de physicis disputant.

70 Etymol., XI, 3, 11: Alia conmixtione generis, ut $\alpha \nu \delta \rho o \gamma v v o \imath$ et $\varepsilon \varphi \mu \alpha \varphi \rho \circ \delta \imath \tau \alpha \imath$ vocantur. Hermaphroditae autem nuncupati eo quod eis uterque sexus appareat...Hi dexteram mamillam virilem, sinistram muliebrem habentes vicissim coeundo et gignunt et pariunt.

Textos medievales

Hispania Sacra 55 (2003) 
satirión ${ }^{71}$. En el reino animal coloca un estigma negativo a algunos de sus integrantes por su sexualidad, contraria a la moral establecida, caso del chivo, «animal lascivo, impúdico, ansioso siempre de copular; debido a esta sensualidad sus ojos miran aviesamente... su miembro fálico es tan ardiente, que con su sola sangre es capaz de disolver el dimante, que ni el fuego ni el hierro pueden trabajarlo» ${ }^{72}$, la sepia, «clase de animal obsceno en su apareamiento, pues concibe por la boca, como las víboras» ${ }^{73}$ (sin duda la práctica del sexo oral era considerada contra natura), la perdiz, «ave falaz e inmunda, pues el macho monta al macho y se olvida de su propio sexo, empujado por la lujuria» ${ }^{74}$. Otros, en cambio, son alabados por sus sanas costumbres sexuales, como la paloma torcaz, que «se le denomina también «ave casta» por sus costumbres, porque es compañera de la castidad; así se dice que, cuando ha perdido a su pareja, continúa solitaria y no vuelve a buscar más el apareamiento» ${ }^{75}$. Algún otro, incluso, es reputado como anti-afrodisiaco, caso del salmonete, ya que «dicen que comiéndolo se aplaca la sensualidad» ${ }^{76}$. El reino vegetal y mineral contiene remedios anticonceptivos, como las semillas del sauce ${ }^{77}$, afrodisiacos, como la ajedra, el satirión, la col rizada y el culantro ${ }^{78}$, anti-afrodisiacos, como

71 Etymol., XVII, 7, 25: Castaneam Latini a Graeco appellant vocabulo..... propter quod fructus eius gemini in modum testiculorum intra folliculum reconditi sunt, qui dum eiciuntur quasi castrantur (Los latinos aplican a la castaña (castanea) un nombre derivado del griego..... porque su fruto, que es doble, se encuentra, a modo de testículos, encerrado en un folículo, que cuando lo sueltan es como si lo castrasen); XVII, 7, 63: Orchades olivae Graeca etymologia a similitudine testiculorum vocatae... (La aceituna orchas tiene una etimología griega, y deriva su nombre de la semejanza con los testículos...); XVII, 8, 2: Tus arbor Arabiae...amygdalae modo sucum aromaticum fundens album... Et appellatur apud nos masculum, eo quod sit natura rotundum in modum testiculorum (El incienso (tus) es un árbol de Arabia...destila un jugo aromático blanco, a manera de almendra, ... entre nosotros se denomina masculum por su conformación redonda, a modo de testículos); XVII, 9, 43: Idem et orchis, quod radix eius in modum testiculorum sit... (Se le llama asimismo orchis, porque su raíz se asemeja a los testículos...).

72 Etymol., XII, 1, 14: Hircus lascivum animal et petulcum et fervens semper ad coitum; cuius oculi ob libidinem in transversum aspiciunt... cuius natura adeo calidissima est ut adamantem lapidem, quem nec ignis, nec ferri domare valet materia, solus huius cruor dissolvat.

73 Etymol., XII, 6, 46: Sepia dicitur...in coeundo obscenum genus; ore enim concipit sicut vipera.

74 Etymol., XII, 7, 63: Perdix... avis dolosa atque inmunda; nam masculus in masculum insurgit, et obliviscitur sexum libido praeceps.

75 Etymol., XII, 7, 62: Palumbes... avis casta ex moribus appellatur, quod comes sit castitatis; nam dicitur quod amisso corporali consortio solitaria incedat, nec carnalem copulam ultra requirat.

76 Etymol., XII, 6, 25: Mullus vocatus... Cuius cibo tradunt libidinem inhibere...

77 Etymol., XVII, 7, 47: Salix dicta... Cuius seminis hanc dicunt esse naturam ut si quis illud in poculo hauserit, liberis careat; sed et feminas infecundas efficit (El sauce (salix)... Afirman que sus semillas tienen tales virtudes que, si uno las toma disueltas en agua, no tiene hijos y a las mujeres las hace infecundas).

78 Etymol., XVII, 9, 42-43 Satureia calida et prope ignita. Unde illi [et] nomen inditum credunt, quod pronos facit in Venerem. Satyrion dicta a Satyris propter incendium libidinis, quam vulgus stincum vocant; Venerem enim suscitat (La ajedra (satureia) es cálida y casi ardiente. Se cree que se 
la lechuga ${ }^{79}$, retardadores de la pubertad, caso del jacinto ${ }^{80}$ y reveladores de la virginidad, como el azabache ${ }^{81}$. También atribuye cualidades a determinadas aguas para influir en el apetito sexual y en la fecundidad humana, por sus propiedades afrodisiacas, antiafrodisiacas, fecundadoras y contraceptivas ${ }^{82}$.

En consecuencia, en Etymologiae San Isidoro ofrece una imagen de la sexualidad humana acorde con la doctrina patrística occidental acerca de estas cuestiones, que es la aceptada y difundida por las jerarquías eclesiásticas y civiles hispanovisigodas, como evidencian los cánones de los concilios hispanovisigodos y el contenido de los corpora legislativos civiles, como la Lex Visigothorum, doctrina que exalta la castidad y contempla exclusivamente un sexo conyugal reproductor, y por tanto, heterosexual. Así el autor desarrolla todo un conjunto de definiciones y razonamientos, con abundantes referencias

le impuso tal nombre porque inclina a la lascivia. De los sátiros deriva su denominación el satirión, debido a que enciende la sensualidad. La gente suele conocerlo como stincus, pues espolea la lascivia); XVII, 10, 21: Carduus. Eruca, quasi uruca, quod ignitae sit virtutis et in cibo saepe sumpta Veneris incendium moveat. Huius species duae, quarum altera usualis, altera agrestis, acrioris virtutis; utraque tamen Veneris commovent usum (Cardo... Col rizada, eruca, es como si se dijera uruca (quemadora), porque tiene unas propiedades abrasadoras y, consumida frecuentemente en la comida, inflama el apetito venéreo. Hay dos especies, de las cuales una es de uso habitual, y la otra es silvestre y de sabor más amargo. Las dos estimulan el apetito venéreo); XVII, 11, 7: Coriandrum... Cuius semen in dulce vino datum proniores reddit in Venerem; si supra modum dederis, amentiam nutrit (El culantro (coriandrum)... su semilla, disuelta el vino dulce, excita la sensualidad. Y si se consume en exceso provoca la locura).

79 Etymol., XVII, 10, 11: Lactuca dicta est quos abundantia lactis exuberet, seu quia lacte nutrientes feminas inplet. Haec et in viris Veneris usum coercet (La lechuga (lactuca) recibió este nombre porque destaca por la abundancia de leche (lac, lactis); o bien porque aumenta la leche de las mujeres que están amamantando. En los hombres disminuye sus deseos eróticos). Curiosamente en el antiguo Egipto se consideraba la contrario, que la lechuga aumentaba la potencia sexual de los varones, al ponerla en relación con Min, el dios de la vegetación y la fecundidad, cfr. F. CIMMINO, Vida cotidiana de los egipcios, Madrid, 2002, p.321. R.M. \& R. HAGEN, Egipto. Hombres, Dioses, Faraones, Barcelona, 2002 (1991), p.139.

80 Etymol., XVII, 9, 15: Hyacinthus... pueros a pubertate retinens (El jacinto... retrasa la pubertad en los niños).

81 Etymol., XVI, 4, 3: Gagates lapis... incensus serpentes fugat, daemoniacos prodit, virginitatem deprehendit (El azabache (gagates)...En estado incandescente hace huir las serpientes, delata a los endemoniados y señala la existencia de la virginidad).

82 Etymol., XIII, 13, 3-5: Cyzici fons amorem Veneris tollit. Boeotiae lacus furialis est, de quo qui biberit ardore libidinis exardescit. In Campania sunt aquae quae sterilitatem feminarum et virorum insaniam abolere dicuntur... Leinus fons Arcadiae abortus fieri non patitur. In Sicilia fontes sunt duo, quorum unus sterilem fecundat, alter fecundam sterilem facit (En Cícico hay una fuente que suprime el apetito venéreo. En Beocia hay un lago que enardece a quienes de él beben y hace que se sientan excitados por los ardores de la lascivia. En Campania hay unas aguas que, según dicen, curan la esterilidad de las mujeres y la locura de los hombres... La fuente Leino, de Arcadia, impide que se produzcan abortos. En Sicilia existen dos fuentes: una de ellas hace fecunda a la mujer estéril, y la otra vuelve estéril a la que es fecunda).

Textos medievales

Hispania Sacra 55 (2003) 
a la antigüedad pagana que sirven de contrapunto, para construir un sólido armazón de conocimientos y ciencia comúnmente aceptada que sirva de sostén a la moral sexual oficial, así como a los principios de la caracterización y diferenciación sexual de hombres y mujeres, y a los consejos para un uso sano y correcto del sexo, con una evidente intención educadora y adoctrinadora del posible lector. Junto a esto, San Isidoro también recoge en su obra un conjunto de creencias y supersticiones, más o menos populares, acerca de la sexualidad y la fecundidad humana, sin duda de escaso fundamento científico pero profundamente arraigados en la mentalidad social de la época. 